\title{
The Relationship between (Meta)cognitive Strategies and Reading Comprehension in Iranian Female L2 Learners
}

\author{
Somayeh Karami ${ }^{1} \&$ Mahmood Hashemian ${ }^{2}$
}

\author{
${ }^{1}$ Department of Foreign Languages, Islamic Azad University, Khorasgan Branch, Isfahan, Iran \\ ${ }^{2}$ English Department, Faculty of Letters \& Humanities, Shahrekord University, Shahrekord, Iran \\ Correspondence: Mahmood Hashemian, English Department, Faculty of Letters \& Humanities, Shahrekord \\ University, Shahrekord, Rahbar Blvd., Iran. Tel: 98-318-442-2517. E-mail: m72h@hotmail.com
}

\author{
Received: May 22, 2012 Accepted: June 16, 2012 Online Published: July 10, 2012 \\ doi:10.5539/ijel.v2n4p58 URL: http://dx.doi.org/10.5539/ijel.v2n4p58
}

\begin{abstract}
The present study aimed to examine the possible effects of the Iranian elementary female L2 learners' (meta)cognitive reading strategy knowledge on their reading comprehension in 3 different stages of reading, that is, prereading, while-reading, and postreading phases. In order to control the language proficiency factor, $40 \mathrm{~L} 2$ learners were selected through the application of the Oxford Placement Test. The participants belonged to 2 different age groups. Twenty of them were selected from the young people, ranging from 15 to 20 years old. The other 20 participants who comprised the second group were adults, ranging from 35 to 40 years old. The participants completed a reading strategy survey and took a reading comprehension test. Descriptive and inferential statistics were used to describe the respondents' reading strategy use and their performance on the reading test. The results showed no significant relationship between the young and adult Iranian female L2 learners' comprehension level and their use of reading strategies. In fact, the data obtained from the young group resulted in a significant relationship between reading comprehension and metacognitive reading strategy use. That is, the more L2 learners employ metacognitive reading strategies, the more their reading comprehension level will be. Besides, the participants of both groups were alike in their perceived use of cognitive reading strategy.
\end{abstract}

Keywords: cognitive strategy, metacognitive strategy, reading comprehension

\section{Introduction}

Reading comprehension is the ability to understand a written text. Undoubtedly, students of any language need to be able to read in that language. Native speakers read a big deal of materials each day depending largely on their motivation for reading. The basic purpose of reading in L1 learning is somehow different from that of L2 learning because it is, indeed, very important in learning an L2. It is all-important at this moment in time. It is remarkably an independent and indispensable skill for the learners who are keen as mustard on learning any language. Reading is considered as the principal skill to learn in order to guarantee doing well in learning (Anderson, 2005). However, the very essence of this skill and the processes it under goes have always been studied.

Hence, the reading process and the factors that affect it have been examined from a long time ago by many researchers (e.g., Anderson \& Pearson, 1984; Cohen, 1998; Garner, 1987). Language experts employ different concepts, such as human psychology and sociology, in order to propose some reading principles and models. The two major reading models are known as bottom-up and top-down (Goodman, 1994). Also, there are some reading strategies that are contributed to reading comprehension, namely (meta)cognitive strategies (Young \& Oxford, 1997). These two models of reading and reading strategies are not distinct. When a reader employs cognitive strategy, the bottom-up model is utilized. The reader tries to construct meaning literally at the sentence level. Whereas, using a metacognitive strategy, the readers engage their background knowledge and constantly check their predictions; therefore, they approach the task employing the top-down model. According to some 
studies, inexperienced readers do not know how to employ the reading strategies, or they just utilize the bottom-up models of reading (Barnett, 1988; Carrell, 1989).

A distinction made by O'Malley and Chamot (1990) divided reading strategies to three categories: cognitive, metacognitive, and social strategies. Cognitive strategies consist of identification, retention, storage, retrieval of words, phrases, and other elements of L2. Metacognitive strategies include preplanning, online planning and evaluation, and postevaluation of L2 learning activities, and L2 use events. These strategies assist L2 learners in planning, organizing, and evaluating of their learning process; therefore, L2 learners can control their cognition. Finally, the actions employed to deal with other L2 learners and native speakers, like questioning for more explanation and doing group work are called social strategies.

Reading strategies refer to both L1 and L2. Even the reading strategy knowledge of L1 can affect that of L2 learners (Yamashita, 2004). "Readers with different levels of L2 proficiency make use of their L1 and L2 to different events in their attempts to make sense of a text they are reading" (Upton, 1997, p. 18). "The learners' language learning strategies have a powerful impact on their learning outcome" (Lengkanawati, 2004, p. 1). Also, Drucker in 2003 approves this notion: "Accomplished readers in their L1 tend to use many of the same strategies that successful native English language readers use (e.g., skimming, guessing in context, and reading for the gist of a text) when they are reading in L2" (Drucker, 2003, p. 1). Hence, the importance of reading strategies in both L1 and L2 cannot be ignored.

To put it simply, metacognition is cognition of cognition (Carrell et al., 1998). It is "thinking about thinking" according to Anderson (2002). Likewise, it is defined as the process of recognizing what is known (Shimamura, 2000). Metacognition is considered a kind of self-assessment. The reader observes the primary stages of reading, which are cognitive activities. Then, supplementary activities (i.e., metacognition) will be assigned in order to provide more awareness and understanding of the text. This study is predominantly an attempt to investigate Iranian female L2 learners' knowledge of cognitive and metacognitive reading strategies in two different age groups and the impact of this knowledge on their reading comprehension ability.

\section{Method}

\subsection{Participants}

The sample selected for this study consisted of a total of 40 participants from about 100 female L2 learners who voluntarily took part in the Oxford Placement Test (OPT; Allen, 2004). As far as the participants' lack of academic knowledge of reading strategies was concerned, the research was conducted to L2 learners of two language schools. Therefore, they had studied English in language schools, not at university as language students The participants belonged to two different age groups. About 55 of them were young adults, ranging from 15 to 20 years old. The other 45 participants who comprised the second group were adults, ranging from 35 to 40 years old. The participant's areas of knowledge were different. The young adults were mostly students majoring in different fields (e.g., computer, law, and medicine). The second group referred to adults consisted of housewives and clerks. Based on the OPT results, 20 learners were randomly selected from each group.

\subsection{Materials}

In order to make a distinction among the female L2 participants studying in the two language schools, a number of questions such as their age and their fields of study were asked. This part was conducted before the OPT. Then the Oxford Placement Test (OPT; Allen, 2004) was used to measure the participants' L2 proficiency. The OPT consisted of listening and grammar sections. The listening section consisted of 100 items uttered in British English. It took approximately ten minutes to complete the listening test. The participants were asked to choose the correct word which they heard in short sentences from two choices. The grammar section consisted of 100 items. Fifty minutes were given for the completion of this part. The participants were asked to read the questions and choose one of the three given options.

The second instrument was a questionnaire measuring the participants' knowledge of reading strategies. For assessing the reading strategies used by the participants during the different stages of reading comprehension, a questionnaire including 27 statements about their perceived use of reading strategies was employed. These statements were both cognitive (13 items) and metacognitive (14 items). The questionnaire was previously tried out by Maghsudi and Talebi (2009). All the 27 items in this study were adopted from different related validated studies (e.g., Baker \& Boonkit, 2004; Oxford, 2004; Sheorey \& Mokhtari, 2001; Taillefer \& Pugh, 1998). The alpha coefficient for the questionnaire was 0.83 , which is considered a high level of reliability. To confirm the validity of the questionnaire, it was presented to a group of $10 \mathrm{~L} 2$ teachers. They were asked to comment on the clarity of items. They approved of the validity of the questionnaire and their comments were implemented to the 
final draft. Besides, to avoid problems in comprehending the strategy statements, they were translated into Persian.

The third test was a reading comprehension test. The passage was taken from the elementary section of the book Steps to Understanding (Hill, 1988). It was a short story on a couple, called Mr. and Mrs. Smith. To examine its reliability, the test was piloted on 10 students. The K-R21 formula was used and the reliability turned out to be 0.70. After calculating the correlation coefficiency $(0.78)$ between the Oxford Placement Test and the reading comprehension test, the test of reading comprehension turned out to be valid for this study. The text was followed by a number of comprehension questions. Six questions required the participants to comprehend the text and choose true or false for each statement. The second part of the questions was comprised of eight questions which required written answers.

\subsection{Procedure}

In order to homogenize the participants in each group, prior to the lunching of the study, in the first week, the OPT was administered to about $100 \mathrm{~L} 2$ learners. According to the criteria, the participants who gain 105-119 are graded as elementary L2 learners. About 40 elementary level participants were randomly selected and assigned to two groups. All the participants in both groups were female.

After detecting the elementary level participants in each group, they were given the reading strategy questionnaire, which was a measure of their reading strategy awareness and use. The questionnaire was translated into Persian in order to provide ease of comprehension for the participants. Besides, the participants' questions were answered, if they had any. Although there was no time limit to fill out this questionnaire, it took less than 20 minutes to be completed.

In the third week, the reading comprehension test was administered to the participants. There was no time limit to do the reading comprehension test, although it did not take more than 30 minutes. The researcher gave the participants the reading comprehension test in order to have an assessment of their reading ability in English and to see to what extent the perceived strategies marked in the previous section were practically employed based on the results.

\section{Results and Discussion}

As for the (meta)cognitive strategy use among young and adult learners, the first part of Table 1 refers to metacognitive strategy:

Table 1. Independent samples test

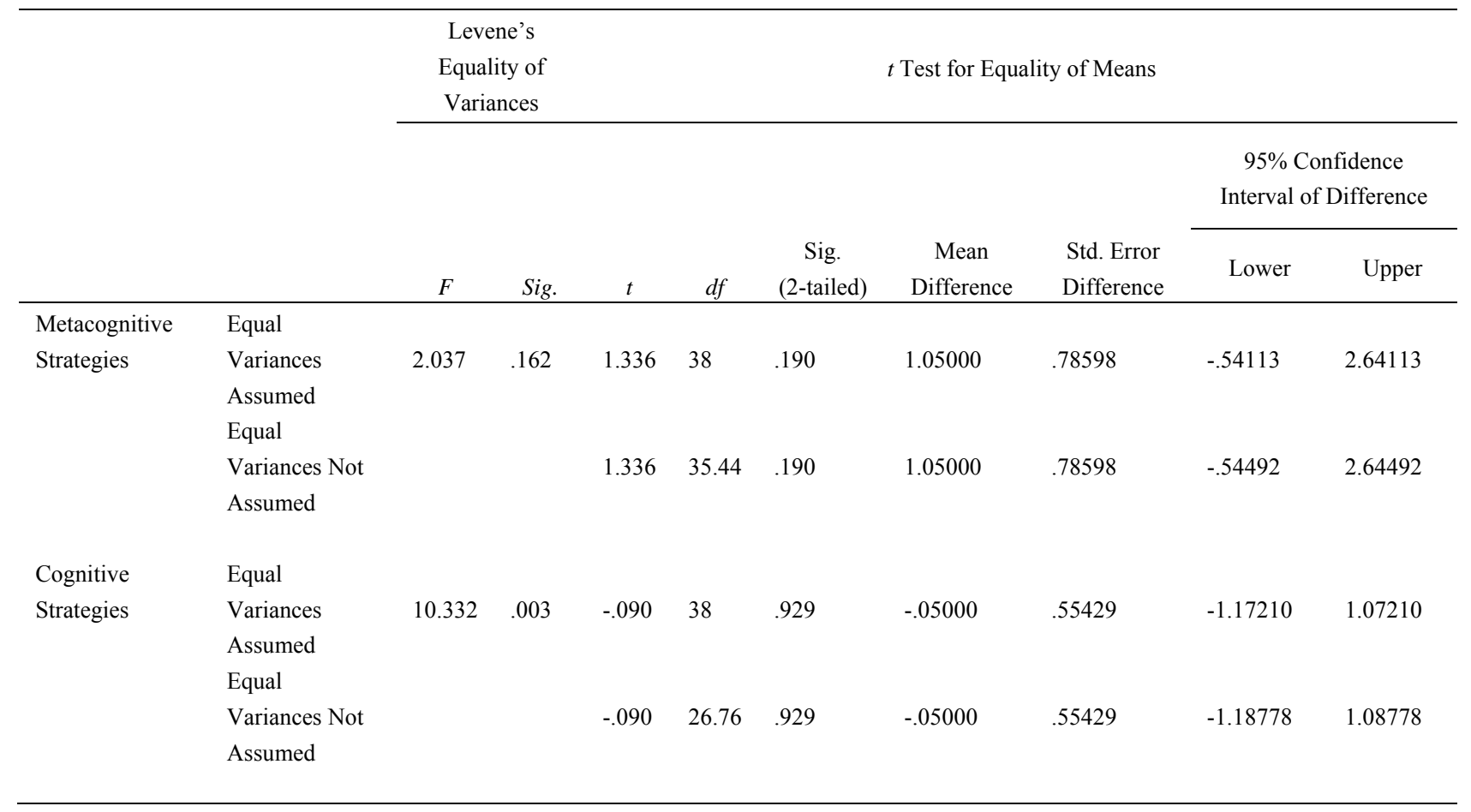


As depicted above, Levene's test for metacognitive strategy was .162 that was more than $\alpha$. Therefore, the variances were equal and the result of $t$ test can be studied. According to the results $(t=1.336, d f=38, \alpha=0.05$, $p=.190), p$ value is more than $\alpha$ and the result is not significant. It means there was no difference between the young and adult learners in using metacognitive strategies.

The second part of the Table 1 deals with cognitive strategy. The Levene's test for cognitive strategy was .003 that was less than $\alpha$. Therefore, the variances were not equal and the results of $t$ test were not acceptable. Hence, a nonparametric test was needed, that was, Mann-Whitney test. The results of this test are displayed in Table 2.

Table 2. Test statistics

\begin{tabular}{ll}
\hline & $\begin{array}{l}\text { Cognitive } \\
\text { Strategies }\end{array}$ \\
\hline Mann-Whitney U & 198.000 \\
Wilcoxon W & 408.000 \\
Z & -.055 \\
Asymp. Sig. (2-tailed) & .956 \\
Exact Sig. [2*(1-tailed Sig.)] & $.968 \mathrm{a}$ \\
\hline
\end{tabular}

Notes: a. Not Corrected for Ties b. Grouping Variable: Group

According to the Mann-Whitney test, the $p$ value is .956 and it was more than $\alpha(\alpha=0.05, p=.956)$. Therefore, the difference between the young and adult learners was not significant statistically. It can be concluded that the young and adult female L2 learners did not differ as far as using cognitive reading strategy was concerned, and the null hypothesis below is not rejected:

There is no significant difference in the reading strategies used by Iranian young and adult L2 learners.

In order to measure the potential relationship between (meta)cognitive strategies and reading comprehension among the young L2 learners, Pearson correlation was run:

Table 3. Pearson correlation for young learners

\begin{tabular}{llccc}
\hline & & $\begin{array}{c}\text { Reading } \\
\text { Comprehension }\end{array}$ & $\begin{array}{c}\text { Metacognitive } \\
\text { Strategies }\end{array}$ & $\begin{array}{c}\text { Cognitive } \\
\text { Strategies }\end{array}$ \\
\hline Reading Comprehension & Pearson Correlation & 1 & $.484^{*}$ & -.214 \\
& Sig. (2-tailed) & & .031 & .364 \\
& $N$ & 20 & 20 & 20 \\
Metacognitive Strategies & Pearson Correlation & $.484^{*}$ & 1 & -.277 \\
& Sig. (2-tailed) & .031 & & .236 \\
& $N$ & 20 & 20 & 20 \\
Cognitive Strategies & Pearson Correlation & -.214 & -.277 & 1 \\
& Sig. (2-tailed) & .364 & .236 & \\
& $N$ & 20 & 20 & 20 \\
\hline
\end{tabular}

Note: *. Correlation is significant at the 0.05 level (2-tailed).

According to the results $(r=.484, \alpha=0.05, p=.031)$, the $p$ value is less than $\alpha$. Therefore, the relationship between reading comprehension and metacognitive reading strategy was significant, and the null hypothesis below is rejected:

There is no significant relationship between using metacognitive reading strategy and reading comprehension level among young elementary female L2 learners.

As for the relationship between cognitive strategy and reading comprehension $(r=.214, \alpha=0.05, p=.364)$, the $p$ value was more than $\alpha$. Therefore, the relationship between reading comprehension and cognitive reading strategy was not significant, and the null hypothesis below is not rejected:

There is no significant relationship between using cognitive reading strategy and reading comprehension level among young elementary female L2 learners. 
In the same way, Pearson correlation was run to measure the potential relationship between (meta)cognitive strategies and reading comprehension among the adult L2 learners:

Table 4. Pearson correlation for adult learners

\begin{tabular}{llccc}
\hline & Reading & $\begin{array}{c}\text { Metacognitive } \\
\text { Ctrategies }\end{array}$ & $\begin{array}{c}\text { Cognitive } \\
\text { Strategies }\end{array}$ \\
\hline Reading Comprehension & Pearson Correlation & 1 & .153 & .168 \\
& Sig.(2-tailed) & & .520 & .478 \\
& $N$ & 20 & 20 & 20 \\
Metacognitive Strategies & Pearson Correlation & .153 & 1 & .302 \\
& Sig.(2-tailed) & .520 & & .196 \\
& $N$ & 20 & 20 & 20 \\
Cognitive Strategies & Pearson Correlation & .168 & .302 & 1 \\
& Sig.(2-tailed) & .478 & .196 & \\
& $N$ & 20 & 20 & 20 \\
\hline
\end{tabular}

According to Table 4 , there was not a significant relationship between reading comprehension and metacognitive reading strategy use among the adult $\mathrm{L} 2$ learners $(r=.153, \alpha=0.05, p=.520)$. Because $p$ value was more than $\alpha$. In addition, the relationship between reading comprehension and cognitive reading strategy was concerned. Accordingly, this relationship was not significant as well $(r=.168, \alpha=0.05, p=.478)$. The $p$ value was more than $\alpha$. Hence, the null hypothesis below is not rejected:

There is no significant relationship between using (meta)cognitive reading strategies and reading comprehension level among adult elementary female L2 learners.

As for the relationship between the participants' reading strategy use and age, a one-way multivariate test was run:

Table 5. Multivariate test ${ }^{\mathrm{b}}$

\begin{tabular}{llcccccc}
\hline \multirow{2}{*}{ Effect } & & & & & & \multicolumn{2}{c}{ Partial } \\
& & Value & $F$ & $\begin{array}{c}\text { Hypothesis } \\
d f\end{array}$ & Error $d f$ & Sig. & $\begin{array}{c}\text { Eta } \\
\text { Squared }\end{array}$ \\
\hline Intercept & Pillai's Trace & .962 & $512.786^{\mathrm{a}}$ & 2.000 & 37.000 & .000 & .965 \\
& Wilks' Lambda & .035 & $512.786^{\mathrm{a}}$ & 2.000 & 37.000 & .000 & .965 \\
& Hotelling's Trace & 27.718 & $512.786^{\mathrm{a}}$ & 2.000 & 37.000 & .000 & .965 \\
& Roy's Largest Root & 27.718 & $512.786^{\mathrm{a}}$ & 2.000 & 37.000 & .000 & .965 \\
& Proup & .046 & $.886^{\mathrm{a}}$ & 2.000 & 37.000 & .421 & .046 \\
& Pillai's Trace & .954 & $.886^{\mathrm{a}}$ & 2.000 & 37.000 & .421 & .046 \\
& Wilks' Lambda & .048 & $.886^{\mathrm{a}}$ & 2.000 & 37.000 & .421 & .046 \\
& Hotelling's Trace & .048 & $.886^{\mathrm{a}}$ & 2.000 & 37.000 & .421 & .046 \\
\hline
\end{tabular}

Notes: a. Exact Statistics b. Design: Intercept + Group

According to the statistics in group cell in Table 5, there was not a significant relationship between the groups and strategy use $(f=.886, p=.421, \alpha=0.05)$. The $p$ value is more than $\alpha$. Hence, the null hypothesis below is not rejected:

There is no significant relationship between learners' reading strategy use and their age.

\section{Conclusion}

Spoken and written are the two forms that any language appears in. The written language involves reading that is a significant skill in learning. Reading effectively and efficiently is of the utmost importance in learning an L2. It is the only supply of words, phrases, expressions, and structures that improves speaking and writing 
simultaneously. But reading in an L2 needs to be done skillfully. One of the most important factors in proficient reading is the awareness of reading strategies. Although different readers apply reading strategies differently, they help the readers in comprehending the text (Treiman, 2001).The present study intended to see if there was any relationship between using (meta)cognitive reading strategy use and reading comprehension among Iranian female L2 learners.

According to the results of the present study, there was a significant relationship between using metacognitive reading strategies and reading comprehension among young elementary L2 learners. Whereas, there was no difference between young and adult learners in employing the reading strategies. Also, there was not a significant relationship between the two groups' age and strategy use.

As Phakiti (2006) maintained, in examining the relationship between reading strategies and reading performance, only cognitive strategies (i.e., comprehending, retrieval, and memory strategies) affect L2 reading comprehension. In another study by Hamdan et al. (2010), the use of (meta)cognitive strategies in reading comprehension was examined among Malaysian L2 learners. The result of their study was in agreement with the current study. It was found that using metacognitive strategies results in high levels of reading comprehension.

Also, the results of another study by Takallou (2011) are in line with the present study to some extent. She inspected the influence of teaching metacognitive strategies (i.e., planning \& self-monitoring) and their possible effects on reading comprehension among Iranian L2 learners. According to the results, the L2 learners who were instructed metacognitive strategies responded the reading comprehension test more successfully.

Alsamadani (2009) investigated the relationship between using reading strategies and reading comprehension among Saudi college L2 learners. He did not find any significant relationship between reading comprehension and strategy use. Compared with strategy use, there were some elements including: background knowledge, vocabulary knowledge, and purpose of the study that affected comprehension more.

In the study by Alsamadani (2009), male and female L2 learners were compared regarding their strategy use while reading. Although the variable of age was not taken into consideration, the female participants proved higher tendency toward strategy use compared with their male counterparts. However, there was not any relationship between strategy use and comprehension level among the female L2 learners.

\section{References}

AD-Heisat, M. A. A., Mohammed, S., Krishnasamy, K. A., \& Issa, J. (2009). The use of reading strategies in developing students' reading competency among primary school teachers in Malaysia. European Journal of Social Sciences, 12(2), 310-320.

Allen, D. (2004). Oxford placement test. Retrieved March 15, 2011, from http://www.amazon.com/Oxford-Placement-Tests-Test-pack/dp/0194309002

Alsamadani, H. A. (2009). The relationship between Saudi EFL college-level students' use of reading strategies and their EFL reading comprehension. Unpublished doctoral dissertation, University of Ohio, College of Education.

Anderson, N. J. (2002). The role of metacognition in second language teaching and learning. Retrieved December 3, 2010, from http://www.cal.org/resources/digest/digest_pdfs/0110_Anderson.pdf

Anderson, N. J. (2005). L2 learning strategies. In E. Hinkel (Ed.), Handbook of research in second language teaching and learning (pp. 757-771). Mahwah, NJ: Lawrence Erlbaum.

Anderson, R. C., \& Pearson, P. D. (1984). A schema-theoretic view of basic processes in reading comprehension. In M. L. Karnil, P. Mosenthal, P. D. Pearson, \& R. Barr (Eds.), Handbook of reading research (pp. 255-291). Mahwah, NJ: Erlbaum Associates.

Baker, W., \& Boonkit, K. (2004). Learning strategies in reading and writing: EAP contexts. RELC, 35(3), 299-328. http://dx.doi.org/10.1177/0033688205052143

Barnett, M. (1988). More than meets the eye: Foreign language reading: Theory and practice. Tappan, NJ: Language in Education.

Carrell, P. (1989). Metacognitive awareness and second language reading. Modern Language Journal, 73, 121-134. http://dx.doi.org/10.1111/j.1540-4781.1989.tb02534.x

Carrell, P., Gajdusek, L., \& Wise, T. (1998). Metacognition and EFL/ESL reading. Instructional Science, 26, 97-112.

Cohen, A. D. (1998). Strategies in learning and using a second language. London: Longman. 
Drucker, J. M. (2003). The reading teacher. Info Trace One File, 57(1), 22-30.

Garner, R. (1987). Metacognition and reading comprehension. Norwood, NJ: Ablex Publishing.

Goodman, K. (1994). Reading, writing, and written texts: A transactional sociolinguistic view. In R. B. Ruddell, M. R. Ruddell, \& H. Singer (Eds.), Theoretical models and processes of reading (pp. 112-130). Newark, DE: International Reading Association.

Grabe, B., \& Stoller, F. (2002). Extensive reading in English as a foreign language. System, 25(1), 91-102.

Hamdan, A. R., Ghafar, M., Sihes, A., \& Atan, S. (2010). The cognitive and metacognition reading strategies of foundation course students in teacher education institute in Malaysia. European Journal of Social Sciences, 13(1), 133-144.

Hill, L. A. (1988). Elementary steps to understanding. Tokyo: Oxford University Press.

Lengkanawati, N. S. (2004). How learners from different cultural backgrounds learn a foreign language. Retrieved May 15, 2004, from http://www.asian-efl-journal.com/04_nsl.htm

Maghsudi, M., \& Talebi, S. H. (2009). The impact of linguality on the cognitive and metacognitive reading strategies Awareness and reading comprehension ability. Journal of Social Sciences, 18(2), 119-126.

O’Malley, J. M., \& Chamot, A. U. (1990). Learning strategies in second language acquisition. Cambridge University Press.

Oxford, R. (2004). Effect of the presence and difficulty of task on strategy use: An exploratory study. International Review of Applied Linguistics, 42, 1-47. http://dx.doi.org/10.1515/iral.2004.001

Phakiti, A. (2006). Modeling cognitive and metacognitive strategies and their relationships to EFL reading test performance. Melbourne Papers in Language Testing, 1, 53-95.

Rigney, J. W. (1978). Learning strategies a theoretical perspective. In H. F. O’Neil (Ed.), Learning strategies (pp. 41-55). New York: Academic Press.

Saricoban, A. (2002). Reading strategies of successful readers through the three phase approach. The Reading Matrix, 2(3), 1-16.

Sheorey, R., \& Mokhtary, K. (2001). Differences in the metacognitive awareness of reading strategies among native and nonnative readers. System, 29, 431-449. http://dx.doi.org/10.1016/S0346-251X(01)00039-2

Shimamura, A. P. (2000). What is metacognition? The brain knows. The American Journal of Psychology, 113(1), 142-146. http://dx.doi.org/10.2307/1423465

Taillefer, G., \& Pugh, T. (1998). Strategies for professional reading in L1 and L2. Journal of Research in Reading, 21(2), 97-108. http://dx.doi.org/10.1111/1467-9817.00047

Takallou, F. (2011). The effect of metacognitive strategy instruction on EFL learners' reading comprehension performance and metacognitive awareness. Asian EFL Journal, 35, 272-300.

Taraban, R., Kerr, M., \& Rynearson, K. (2000). College students' academic performance and self-reports of $\begin{array}{lllll}\text { comprehension strategy use. Reading 283-308. } & \text { Psychology, }\end{array}$ http://dx.doi.org/10.1080/027027100750061930

Treiman, R. (2001). Reading. In M. Aronoff \& J. Rees-Miller (Eds.), Blackwell handbook of linguistics (pp. 664-672). Oxford, England: Blackwell.

Upton, A. (1997). First and second language use in reading comprehension strategies of Japanese ESL students. Retrieved June 17, 2005, from http://www-writing.berkeley.edu/TESL-EJ/ej09/a3.html

Yalcin, S. K., \& Sengul, M. (2004). A model proposal prepared for developing reading and comprehension skills. Journal of National Education, 5, 164-183.

Yamashita, J. (2004). Reading attitudes in L1 and L2, and their influence on L2 extensive reading. Retrieved June 17, 2005, from http://nflrc.hawaii.edu/rfl/April2004/yamashita/yamashita.html

Young, D., \& Oxford, R. (1997). A gender-related analysis of strategies used to process input in the native language and foreign language. Applied Language Learning, 8, 43-73. 